THE MANAGEMENT OF SEDIMENT TRANSPORTED BY GLACIAL

\title{
MELT-WATER STREAMS AND ITS SIGNIFICANCE FOR THE ESTIMATION OF SEDIMENT YIELD
}

\author{
by
}

A. Bezinge,

(Grande Dixence S.A., CH-1950 Sion, Valais, Switzerland)

\author{
M.J. Clark, A.M. Gurnell, and J. Warburton
}

(Department of Geography, University of Southampton, Southampton SO9 5NH, England, U.K.)

\begin{abstract}
This paper describes the calibration of sediment traps in melt-water intake structures of the Grande Dixence hydro-electricity scheme for the purpose of generating medium-term estimates of suspended sediment and bedload transport by pro-glacial streams. The frequency of emptying/purging of sediment from traps in 17 glacier basins in the Val d'Hérens is combined with their design sediment volume to provide first approximations of the mean annual volume of sediment purged. This is followed by more detailed consideration of 11 years of records from three of the basins, to investigate mean seasonal and inter-annual patterns of purging. The difficulties of relating sediment purging to sediment transport are considered. A sediment calibration strategy based on 2 years of turbidity records, hand sampling of suspended sediment concentration, and monitoring of the accumulation of sediment in sediment traps is proposed for one of the glacier basins, and is checked using hourly and $4 \mathrm{~h}$ suspended sediment observations from two further ablation seasons. The calibration is applied to 10 years of discharge and purge records to establish estimates of mean seasonal and inter-annual patterns of suspended sediment and bed-load transport.
\end{abstract}

\section{INTRODUCTION}

Long records of suspended sediment yield from alpine glacier basins are rare and, even where several years of record exist, the sampling has usually been infrequent. Indeed, with the exception of the frequent observations of suspended sediment concentration, such as those recorded by Kjeldsen (1981), collected over many ablation seasons for a number of pro-glacial streams in Norway, sampling design and length of observation period employed on proglacial streams are usually inadequate for investigating the magnitude, variability, and controls of pro-glacial suspended sediment yield. A survey of the published literature (Gurnell, 1987) provided 43 glacier basins (in the Western Cordillera of North America, the European Alps, Greenland, the Himalaya, Scandinavia, Spitsbergen, and Soviet Central Asia) with estimates of discharge and suspended sediment yield for at least one ablation season, but with great variability in the sampling framework.

Information on bed-load yield from alpine glacier basins is even rarer than that for sediment yield because of logistical problems in monitoring bed-load transport in these high-energy and remote environments (Raemy and Jaeggi, 1981: Bathurst, 1987). However, techniques based on surveys of the deposition of bed load at fixed sites, such as behind a fence traversing the pro-glacial stream (Hammer and Smith, 1983), within gravel sedimentation chambers (Wold and Østrem, 1979), and as deltaic deposits in pro-glacial lakes (Kjeldsen and Østrem, 1980), have provided estimates of bed-load yield for a few pro-glacial streams.

This paper considers the potential of detailed field calibrations of sediment traps in melt-water intake structures within a hydro-electricity scheme for estimating sediment yield. Previously data from sediment traps associated with hydro-electric power schemes have been used both for estimating sediment transport (Wold and Østrem, 1979; Lauffer and Sommer, 1982) and as an approximate means of estimating bed-load transport during a melt-water outburst from the Tsidjiore Nouve basin, Switzerland (Beecroft, 1983). In this paper no specific particle size is used to distinguish suspended sediment load from bed load. Suspended sediment load is taken to be that part of the bed-load material which at any time is carried in suspension in the river, whereas bed load is that part of the load which is transported by rolling, sliding or saltation along the bed.

MANAGEMENT OF SEDIMENT IN THE GRANDE DIXENCE HYDRO-ELECTRICITY SCHEME

In southern Switzerland, the Grande Dixence hydroelectricity scheme collects melt water from 35 drainage

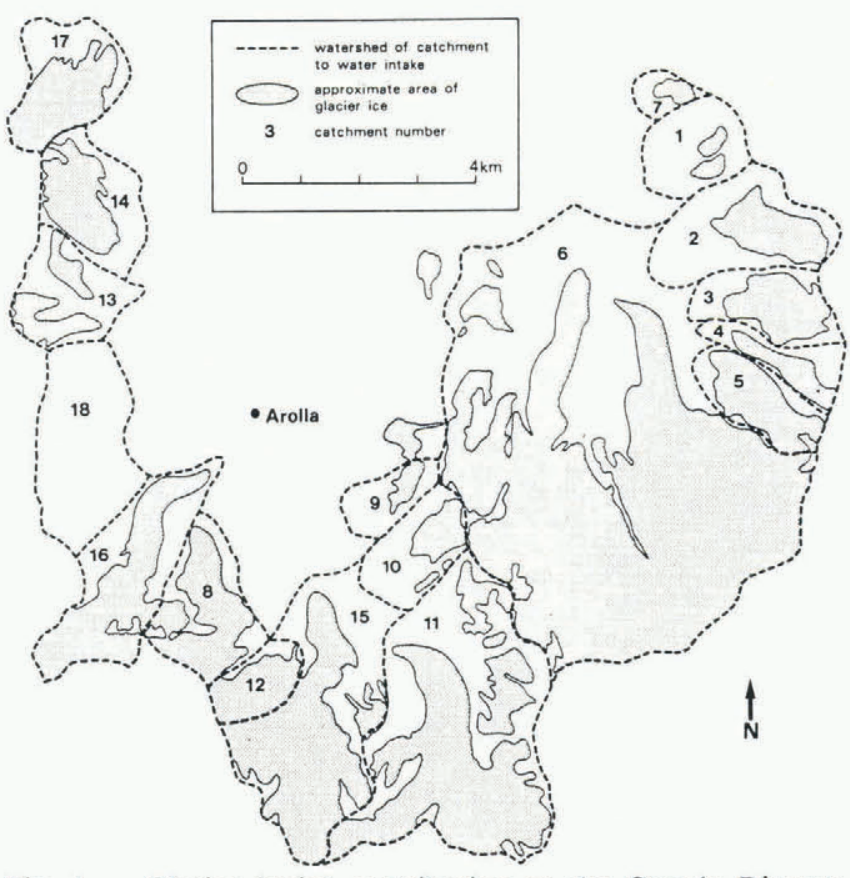

Fig. 1. Glacier basins contributing to the Grande Dixence hydro-electricity scheme in the Val d'Herens. 
TABLE I. PRELIMINARY ESTIMATES OF MEAN SEDIMENT YIELD FOR BASINS OF VAL D'HERENS, BASED ON PURGING OF WATER-INTAKE SEDIMENT TRAPS (1970-80)

Water intake
Mean volume of material evacuated in each purge

\section{Mean annual number of purges}

Mean annual volume of material purged

$$
\left(\mathrm{m}^{3}\right)
$$

1 Les Rosses

Bricola

Dent Blanche

Rocs Rouge

Manzettes

Ferpècle

Mourti

Piece

Douves Blanches

Bertol Sup.

Haut Arolla

Vuibé

Ignes

Aiguilles Rouges $x$

5 Bas Arolla: sand

$$
\text { gravel }
$$

16 Tsid. Nouve: sand

17 Vouasson gravel

18 Fontainesses (negligible sediment yield)

$\begin{array}{cr}\mathrm{x} & 25 \\ \mathrm{x} & 20 \\ \mathrm{x} & 25 \\ \mathrm{x} & 25 \\ \mathrm{x} & 25 \\ \mathrm{x} & 5 \\ & 3 \\ & 10 \\ \mathrm{x} & 20 \\ & 15 \\ \mathrm{x} & 100 \\ & 20 \\ & 15 \\ & 20 \\ \mathrm{x} & 8 \\ \mathrm{x} & 150 \\ \mathrm{x} & 7 \\ \mathrm{x} & 70 \\ \mathrm{x} & 20\end{array}$

Total basins in the Alpine valleys of St. Nicolas and Hérens. Sediment transported in melt water can block or cause erosion of melt-water intake structures and collecting tunnels, cause sedimentation in balancing basins and in the main storage reservoir, and induce wear on pumps and turbines. For these reasons, the majority of the Grande Dixence melt-water intake structures incorporate sediment traps which intercept both bed load and a part of the suspended load. These intake structures provide accurate discharge measurements and also, through the aperiodic emptying/purging of sediment traps, an indication of the amounts of sediment transported. Figure 1 shows the 18

$\begin{array}{rr}8 & 200 \\ 7 & 140 \\ 4 & 100 \\ 6 & 150 \\ 9 & 205 \\ 20 & 100 \\ 10 & 30 \\ 17 & 170 \\ 6 & 120 \\ 10 & 150 \\ 58 & 5800 \\ 10 & 200 \\ 10 & 150 \\ 16 & 320 \\ 80 & 640 \\ 106 & 15900 \\ 50 & 350 \\ 56 & 3920 \\ 30 & 600\end{array}$

approximately $\quad 30000$

basins contributing melt water to the scheme in the Val d'Hérens; the basin names are listed in Table $I$. With the exception of the ice-free Fontainesses basin, all of the basins include a glaciated area and all yield significant amounts of sediment.

Sediment traps of various designs are used in the basins. In many cases a single trap intercepts all bed load and a part of the suspended load, but in the basins of the Glacier de Tsidjiore Nouve and the Bas Glacier d'Arolla, two separate traps intercept sediment (Fig. 2). A "gravel" trap collects bed load and some suspended load, and a "sand" trap collects a further part of the suspended load.

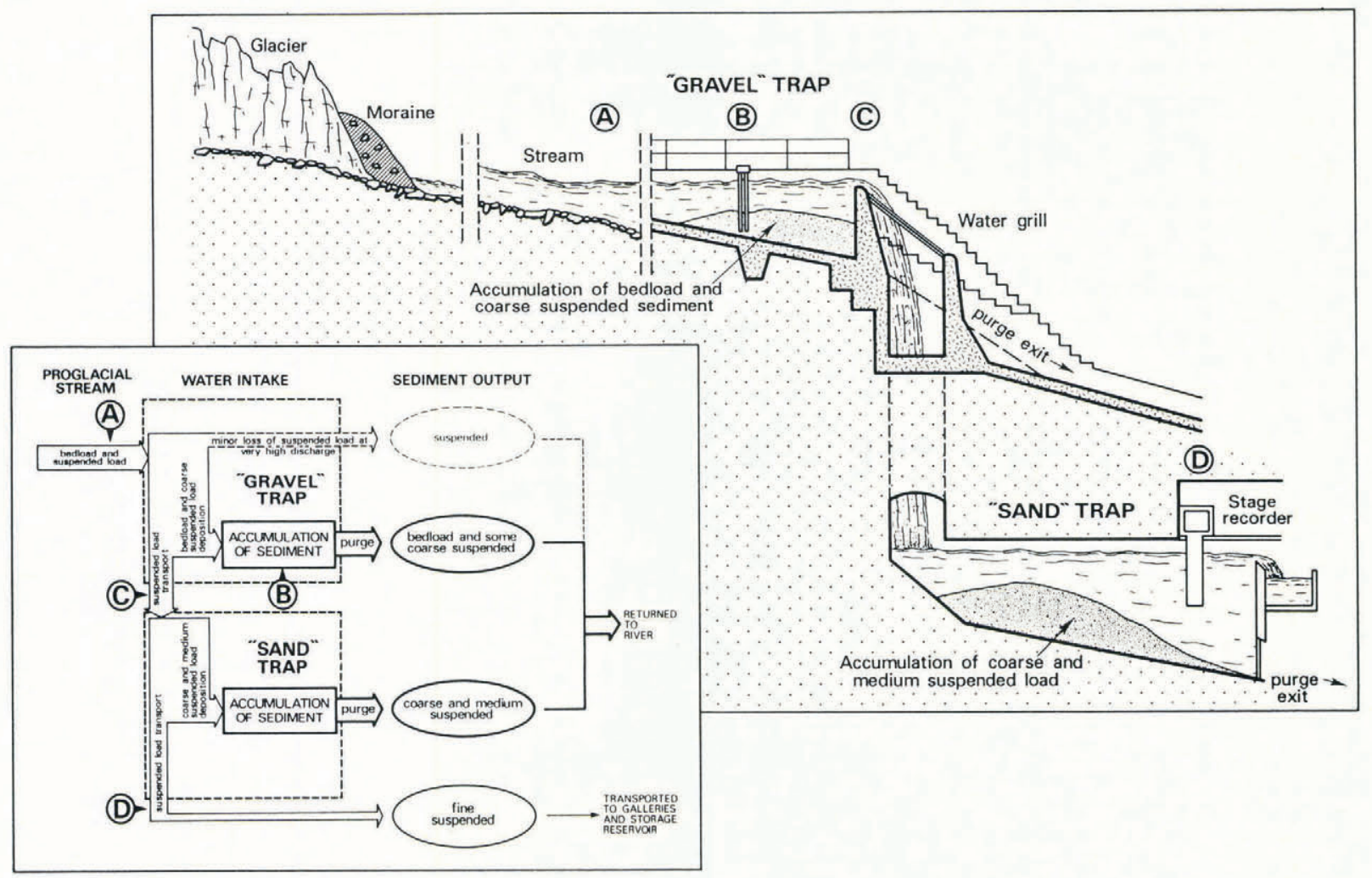

Fig. 2. Schematic diagram of the Tsidjiore Nouve and Bas Arolla melt-water intake structures. 
Some traps are manually purged but the majority are purged automatically when a predetermined level of sediment accumulation is sensed. During trap purging the flow of the melt-water stream is temporarily diverted down its natural course, thus causing a reduction of flow through the trap intake which can be identified on the water-stage recorder chart (Fig. 2, site D). Where two traps are used, the water stage drops to different levels when the different traps are purged.

Table I provides a first approximation of the mean annual volume of sediment purged from sediment traps in the Val d'Herens, based both on the design volume for sediment trapped and on the average number of purges over a 10 year period. Table $\mathrm{I}$ indicates a variability in volume of sediment purged which is thought to reflect genuine differences in sediment yield, although it is important to bear in mind the limitations on the data. Manually purged basins are those where frequent purging is not normally required, but where it is possible either that the traps may fill between maintenance visits or that they may be purged before they are full, leading respectively to under or overestimates of sediment yield. Manual purges may be undertaken for maintenance of automatically purged traps, leading to overestimates of sediment yield if they are not identified as manual from the water stage records (site D, Fig. 2). In addition, the actual amount of sediment trapped may differ from the design value amount and differences in the packing density of trapped sediment may result in major differences in the weight of sediment purged. Finally, efficiency of the sediment traps, i.e. the percentage of incoming sediment actually trapped, may vary between traps of different size and design and also between traps of the same design because of differences in the calibre and density of the incoming sediment, and also because of differences in the energy characteristics of pro-glacial streams as they enter the traps.

\section{TEMPORAL CHARACTERISTICS OF SEDIMENT-TRAP} PURGES IN THREE GLACIER BASINS

Purges of the single sediment trap in the Haut Arolla water intake and of both the "gravel" and "sand" traps in the Bas Arolla and Tsidjiore Nouve intakes were identified on water stage records from 1977 to 1987 inclusively. Malfunctioning of the recorder made differentiation of the two types of purge difficult in 1982 for Bas Arolla and in 1978 for Tsidjiore Nouve, and so these years were excluded from the final analysis. In addition, maintenance work on the Haut Arolla intake over a prolonged period during 1985 yielded a low total of purges for that year. For the present analysis, manual purges have been omitted from the purge records of automatic traps so that estimates of purge frequency assume filling of the traps in each case.

Figure 3 shows average weekly purge frequency over the 11 year period in comparison with the average weekly run-off volumes for the same period, and discharge records are used only for the years for which purge data is available. No trap purging occurs in the first 2-3 weeks of melt-water flow, and there appears to be a slight lag in the

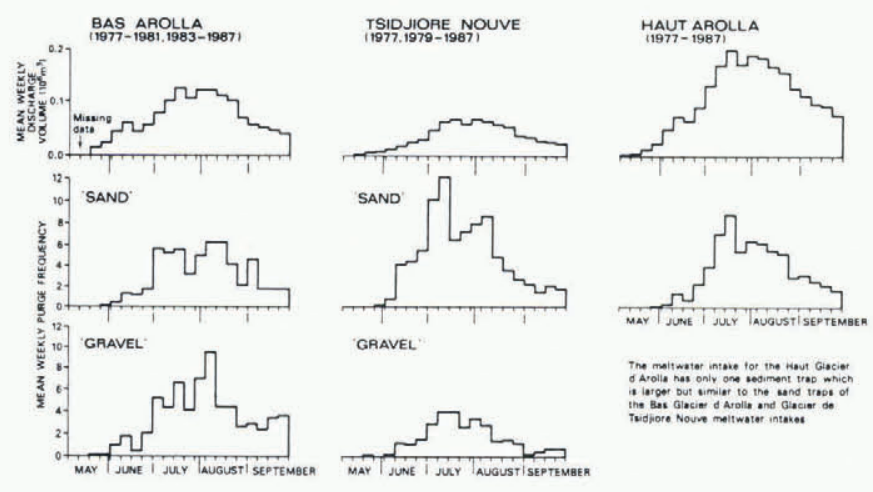

Fig. 3. Mean weekly melt-water discharge and purge frequency - Haut Arolla, Bas Arolla, and Tsidjiore Nouve basins.
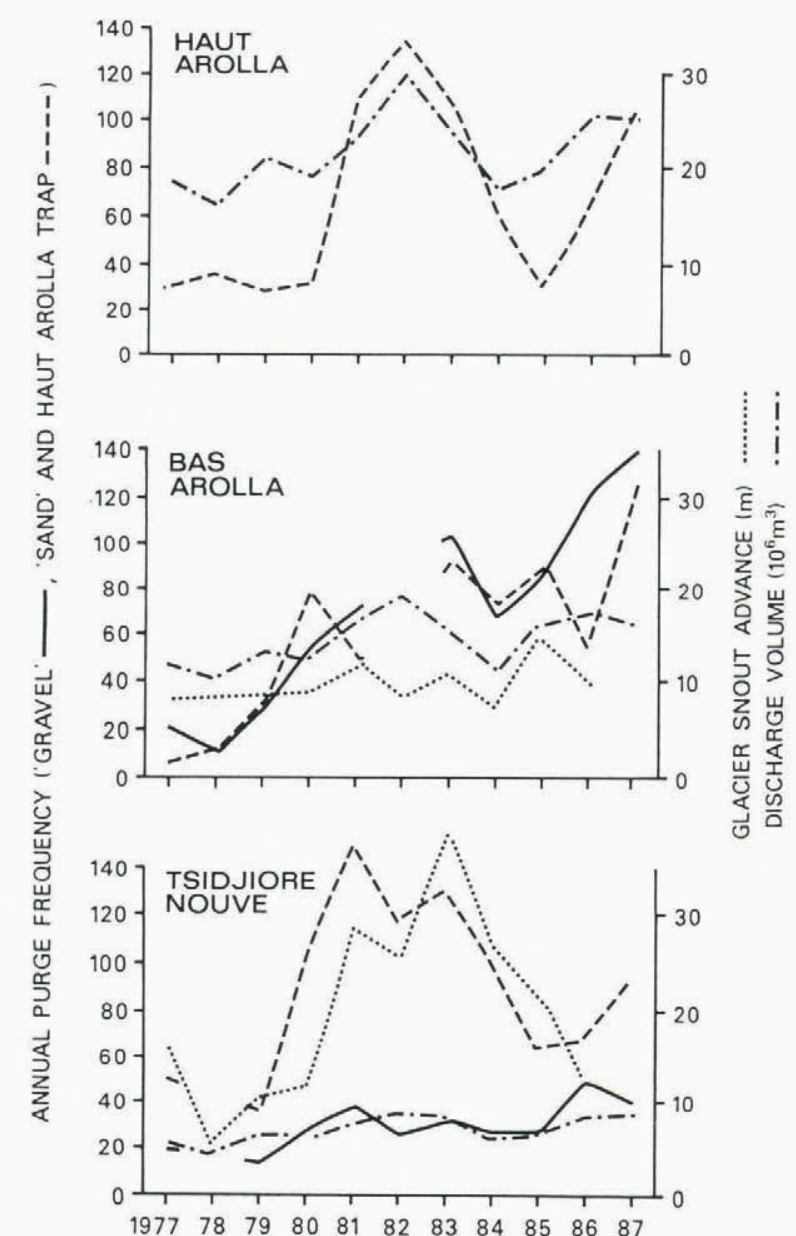

Fig. 4. Annual purge frequency in relation to annual discharge volume and glacier-snout advance - Haut Arolla, Bas Arolla, and Tsidjiore Nouve.

purging of the "gravel" traps after the "sand" traps for both the Bas Arolla and Tsidjiore Nouve streams, which may indicate differences in temporal phasing of bed load and suspended sediment transport.

Figure 4 shows the pattern of annual purge frequency, annual discharge volume and (for Tsidjiore Nouve and Bas Arolla) variations in annual glacier-snout advance. There is a general trend of increased values in all four variables over the study period for the Bas Arolla basin. Data for Tsidjiore Nouve show an initial increase followed by a decrease in both "sand" trap purges and glacier-snout advance, but a generally increasing trend in "gravel" trap purges and in discharge.

It is difficult to make useful comparisons between the purge frequencies shown in Figures 3 and 4 because the sediment traps differ in type and capacity, and the amount and particle-size distribution of the sediment delivered to the traps may also differ, leading to differences in packing density of the sediment. For example, observations of suspended sediment concentration entering and leaving the "gravel" traps at the Bas Arolla and Tsidjiore Nouve intake structures indicate that very little suspended sediment is deposited in the Bas Arolla trap, although a considerable amount is deposited in the Tsidjiore Nouve trap. This suggests that the purges of the two traps reflect the pattern of bed-load and suspended load transport for Bas Arolla but not for Tsidjiore Nouve. In addition, from observations of sediments deposited in containers suspended in the "gravel" traps, material deposited in the Bas Arolla trap is coarser and has a lower packing density (mean $=1.3$ tonnes $\mathrm{m}^{-3}$; standard deviation $=0.1$ tonnes $\mathrm{m}^{-3} ; \quad n=9$ ) than the sediment deposited in the Tsidjiore Nouve trap (mean $=1.63$ tonnes $\mathrm{m}^{-3}$; standard deviation $=0.1$ tonnes $\mathrm{m}^{-3}$. $n=16$ ) in spite of the similar bulk density of the material from which the trapped sediment was derived $\left(\right.$ mean $=2.57$ tonnes $\mathrm{m}^{-3}$, standard deviation $=$ 0.16 tonnes $\left.\mathrm{m}^{-3} ; \quad n=8\right)$. It is essential, through field 
calibration, to translate the purges into comparable quantities of transported sediment before reliable inter-basin comparisons can be made.

\section{TRAP-CALIBRATION STRATEGY}

Calibration of the purges from the "gravel" and "sand" traps of the Tsidjiore Nouve intake illustrate how this can provide quantitative information about sediment transport.

Water turbidity was monitored continuously at site D (Fig. 2) from 25 May to 2 September 1986, and again from 6 June to 7 September 1987 using a Partech 7000-series model 3RP suspended solids monitor. These records were transformed into estimates of suspended sediment concentration at sites A, C and D by hand sampling. Water samples, collected at the three sites using a USDH 48 sampler, were filtered through pre-weighed Whatman 40 filter papers. The suspended sediment concentration determined from the water samples was related to the turbidity of the same water parcel as it passed the turbidity probe at site D (flow time between the three sites was estimated using a salt tracer) to derive suspended sediment concentration calibration curves for the three sites (A, C, D) in relation to turbidity at site D. In all three cases clear relationships were established between turbidity and suspended sediment concentration (for example, in 1987 samples were taken during June, July, and early August to cover a wide range of turbidity values yielding the following: site A: $R^{2}=0.92, n=29$; site $\mathrm{C}: R^{2}=0.97$, $n=23$; site D: $R^{2}=0.96, n=53$ ). Both the calibration curves and the continuous turbidity record provided estimates of suspended sediment concentration at the three sites throughout the 1986 and 1987 ablation seasons, and thus an estimation of the amount of suspended sediment deposited between the sites in the "gravel" and "sand" traps. The amount of sediment deposited divided by the number of trap purges yielded similar values for the 2 years; an estimate of 50.5 tonnes of suspended sediment evacuated by each automatic "gravel" trap purge and 19 tonnes evacuated by each automatic "sand" trap purge. The traps purge independently when they are full but on average $27 \%$ of the total incoming suspended sediment is deposited in the gravel trap and $11.5 \%$ is deposited in the sand trap, with a further $61.5 \%$ of total incoming suspended sediment passing through both traps.

The volume of bed-load transport was estimated from surveys of the surface profile of sediment accumulating in the "gravel" trap (site B, Fig. 2). In order to derive the weight of sediment purged the difference in the volume of accumulated sediment immediately before and after purging was multiplied by packing density. Only five automatic purges have been observed in detail so far (mean volume purged is approximately $120 \mathrm{~m}^{3}$ ). All of these purges occurred during the day, efficiently clearing the trap. However, the lower river flows at night may clear the trap less efficiently. A preliminary estimate of the likely volume range of sediment purged during an automatic purge of the "gravel" trap $\left(105-135 \mathrm{~m}^{3}\right)$ has been made using the geometry of the trap, the location of the sensors which induce purging, and envelope profiles around the observed accumulation of sediment before and after purging. The estimated range is larger than the trap design volume, and appears to result from deposition of sediment at the entry to the trap, up-stream of the sensors. All of the bed load and some of the suspended sediment is deposited in the "gravel" trap. The estimated weight of 50.5 tonnes of suspended sediment removed by each purge of the "gravel" trap is subtracted from the total weight of sediment purged to arrive at the quantity of bed load (approximately 120-170 tonnes per automatic purge).

The accuracy of suspended sediment yield estimates from purge records was checked using hourly records of suspended sediment concentration for 3 months of 1981, and a similar period of $4 \mathrm{~h}$ records in 1982. Estimates of 8730 tonnes and 7670 tonnes of suspended sediment transport in the two observation periods were derived from the filtration of water samples $(>250 \mathrm{ml})$ abstracted from the centre of the Tsidjiore Nouve stream up-stream of the melt-water intake using an Automatic Liquid Samplers Mk4B sampler. These totals were corrected to loads appropriate to sampling by a USDH 48 sampler, using a field calibration curve of paired values derived from the ALS Mk4B and a USDH 48 in $1981\left(n=23, R^{2}=0.97\right)$. The corrected "observed" yields of 9230 tonnes and 8100 tonnes were within $6 \%$ of suspended sediment yields of 9560 tonnes and 8590 tonnes estimated from the trap purges during the same three months in 1981 and 1982 and the field calibrations of the amount of suspended sediment deposited in, and passing through, each trap.

This methodology for trap calibration makes many assumptions. It assumes that the same proportion of suspended sediment or bed load is trapped in the "gravel" trap throughout the ablation season, and that a similar amount of sediment accumulates between purges. However, checks of suspended sediment yield using observed suspended sediment transport in 1981 and 1982 suggest that the approach provides acceptable average values over an ablation season.

\section{ESTIMATION OF SEDIMENT TRANSPORT FROM CALIBRATED SEDIMENT-TRAP PURGES}

Figures 5 and 6 show estimates of the mean ablationseason pattern of weekly suspended sediment and discharge yield and of the inter-annual variations in sediment yield from the Tsidjiore Nouve basin. Figure 5 indicates negligible sediment transport during the May to early June snow-melt period, a period of increasing discharge in response to ablation of glacier ice and high sediment transport during late June and July, and finally a period from late July to September of declining discharge and rapidly declining sediment load as sediment supply becomes limited.

The pattern seen in the upper graph in Figure 6 is different from that indicated by the purge data from which the graph was derived (Fig. 4). This results from two factors; that the "sand" trap has a much smaller capacity than the "gravel" trap, and that more suspended sediment is deposited in the "gravel" trap than in the "sand" trap during each inter-purge accumulation. Figure 6 illustrates the strong influence of annual discharge on sediment yield and the enhanced sediment yields in years with high glacier-snout advance.

\section{DISCUSSION}

Sediment-trap purging can provide useful information about sediment transport in the pro-glacial streams tapped by the Grande Dixence scheme, but field calibrations of the sediment traps are necessary in order to derive reliable estimates of sediment yield. Whereas the Bas Arolla traps have preliminary field calibrations which appear to quite closely match their design specification, those for Tsidjiore Nouve indicate that more sediment is trapped than would be predicted from the design values. The Tsidjiore Nouve design values might represent a reasonable average if manual purges were to be included in the sediment yield estimation, but it is not possible to establish this without more detailed field calibration data. In the meantime, the estimates

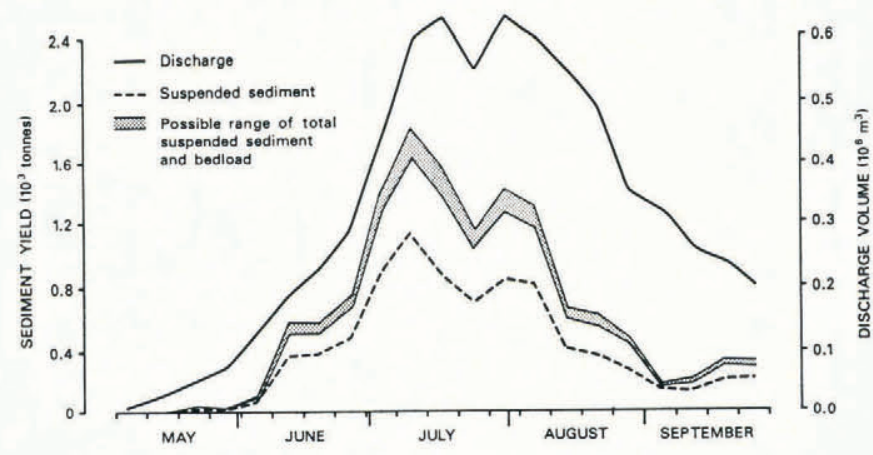

Fig. 5. Mean weekly melt-water discharge, and estimated suspended-sediment and bed-load yield (1977, 1979-87) from the Tsidjiore Nouve basin. 

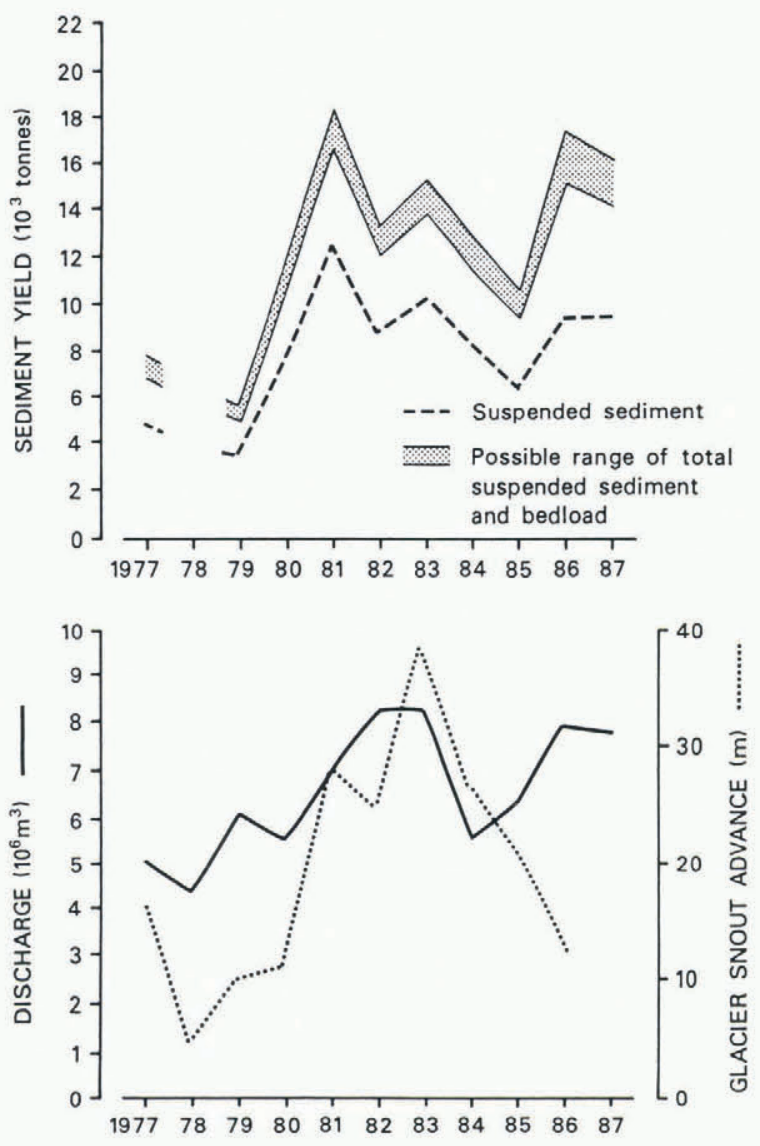

Fig. 6. Estimated annual sediment yield (1977, 1979-87) from the Tsidjiore Nouve basin in relation to annual discharge volume and glacier-snout advance.

presented in this paper are mininum values based only on the automatic purging of traps after complete filling. The methodology provides quite accurate estimates of suspended sediment transport over an ablation season, and it can form a basis for estimating sediment transport during large discharge events when monitoring bedload by alternative means might be impossible. In addition, it provides a means of comparing sediment yields from glacier basins in a consistent manner which could be extended to other basins within the Grande Dixence scheme to reveal the regional pattern of sediment yield.

From the 10 years of analysis for the Tsidjiore Nouve basin, it has been estimated that bed load forms between 25 and $38 \%$ of the total annual sediment yield of suspended sediment plus bed load if the lower error margin for trapped bed load is employed, and between 32 and $46 \%$ if the upper margin is used. The mean total annual sediment yield from the basin over the 10 year period is calculated to be between 12000 tonnes and 14000 tonnes, which is equivalent to an average annual denudation rate over the whole catchment area in the range of $0.97-1.13 \mathrm{~mm}$. These estimates from the basin of the Glacier de Tsidjiore Nouve can be compared with mean suspended sediment concentrations for the 43 basins in the Gurnell (1987) survey. Tsidjiore Nouve exhibits the eleventh highest suspended sediment concentration (approximately $1260 \mathrm{mg} \mathrm{l}^{-1}$ ). The highest concentrations, of over $5000 \mathrm{mg} \mathrm{l}^{-1}$, occurred on the Hunza River (Ferguson, 1984) and from the Fedchenko Glacier (Chernova, 1981); the lowest concentrations, of less than $80 \mathrm{mg} \mathrm{l}^{-1}$, were from the basins of three Norwegian glaciers, Nigardsbreen, Engabreen, and Bondhusbreen (Kjeldsen and Østrem, 1980); and the median value of approximately $830 \mathrm{mg} \mathrm{t}^{-1}$ occurred in the Hilda Glacier basin (Hammer and Smith, 1983).

\section{ACKNOWLEDGEMENTS}

The U.K. Natural Environment Research Council is gratefully thanked for the provision of a research studentship to J. Warburton. I. Beecroft collected the pumped samples in 1981 and 1982.

\section{REFERENCES}

Bathurst, J.C. 1987. Measuring and modelling bedload transport in channels with coarse bed materials. In Richards, K.S., ed. River channels: environment and process. New York, Basil Blackwell, 272-294.

Beecroft, I. 1983. Sediment transport during an outburst from Glacier de Tsidjiore Nouve, Switzerland, 16-19 June 1981. J. Glaciol., 29(101), 185-190.

Chernova, L.P. 1981. Influence of mass balance and run-off on relief-forming activity of mountain glaciers. Ann. Glaciol., 2, 69-70.

Ferguson, R.I. 1984. Sediment load of the Hunza River. In Miller, K.J., ed. The International Karakoram Project. Vol. 2. Cambridge, etc., Cambridge University Press, 581-598.

Gurnell, A.M. 1987. Suspended sediment. In Gurnell, A.M. and M.J. Clark, eds. Glacio-fluvial sediment transfer: an alpine perspective. Chichester, etc., John Wiley and Sons, 305-354.

Hammer, K.M. and N.D. Smith. 1983. Sediment production and transport in a proglacial stream: Hilda Glacier, Alberta, Canada. Boreas, 12(2), 91-106.

K jeldsen, O. 1981. Materialtransportundersøkelser i norske breelver. Norges Vassdrags- og Elektrisitetsvesen. Vassdragsdirektoratet. Hydrol. Avd. Rapp. 4-81.

Kjeldsen, O. and G. Østrem. 1980. Materialtransportundersøkelser i norske breelver. Norges Vassdrags- og Elektrisitetsvesen. Vassdragsdirektoratet. Hydrol. Avd. Rapp. 1-80.

Lauffer, H. and N. Sommer. 1982. Studies on sediment transport in mountain streams of the eastern Alps. Commission Internationale des Grands Barrages (4th Congress, Rio de Janeiro, 1982) 431-453.

Raemy, F. and M. Jaeggi. 1981. Some problems related to sediment transport measurement in steep mountain streams. International Association of Hydrological Sciences Publication 133 (Symposium at Florence 1981 - Erosion and Sediment Transport Measurement), 231-239.

Wold, B. and G. Østrem. 1979. Subglacial constructions and investigations at Bondhusbreen, Norway. J. Glaciol., 23(89), 363-379. 